\title{
Geochemistry of Coexisting Biotite and Muscovite of Portuguese Peraluminous Granitic Differentiation Series
}

\author{
A. M. R. Neiva ${ }^{1, \star}$. M. M. V. G. Silva ${ }^{1}$, M. E. P. Gomes ${ }^{2}$ and T. F. C. Campos ${ }^{3}$ \\ 1 Department of Earth Sciences, University of Coimbra, Coimbra, Portugal \\ 2 Department of Geology, University of Trás-os-Montes e Alto Douro, Vila Real, Portugal \\ 3 Department of Geology, Federal University of Rio Grande do Norte, Natals, Brazil
}

Received: 5. 10. 2000 - Accepted: 18. 2. 2002

\begin{abstract}
In nine Portugese peraluminous Hercynian granitic series of differentiation, $\mathrm{Cr}, \mathrm{V}, \mathrm{Sc}$ and $\mathrm{Ba}$ decrease, whereas $\mathrm{Nb}, \mathrm{Zn}, \mathrm{Sn}, \mathrm{Li}, \mathrm{Rb}$ and $\mathrm{Cs}$ increase in the sequence of micas crystallization. Commonly equilibrium was not attained for trace elements between coexisting primary biotite and muscovite. Correlations of $\mathrm{Cr}, \mathrm{V}, \mathrm{Nb}, \mathrm{Li}, \mathrm{Rb}$ and $\mathrm{Cs}$ were found for biotite-muscovite pairs. The same correlation has a different slope in distinct series due to distinct degree of fractional crystallization, but also to solid-liquid reequilibration during late-magmatic evolution, as suggested by regression lines, which do not generally pass through the origin. Most trace elements partition in favour of biotite, while Sn, Sc, Sr and Ba prefer muscovite. These micas probably crystallized simultaneously as suggested by intergrowths. The partition ratio for $\mathrm{Cs}$ is one series is similar to that found experimentally.
\end{abstract}

Key words: biotite, muscovite, equilibrium, direquilibrium, granitic differentiation series

\section{Introduction}

Micas are important in the evolution of peraluminous granitic series. Major and trace elements of micas give good information during the evolution of granitic magmas (e.g.,

\section{* Corresponding author:}

A. M. R. Neiva, Department of Earth Science, University of Coimbra, 3000-272 Coimbra, Portugal

Tel.: ++351-239823 022; Fax: ++351-239 837 711; e-mail: neiva@ci.uc.pt 
Neiva 1973, 1977, 1993, 1998; Albuquerque 1975; Neiva and Gomes 1991; Neiva et al. 1987; Hall et al. 1993; Silva and Neiva 1990, 2000; Tischendorf et al. 2001). The crystal chemistry of coexisting biotite and muscovite from peraluminous granites seems to be a good indicator of chemical events during crystallization, as shown by Brigatti et al. (2000).

Partition coefficients are dependent on composition of minerals, temperature, and the degree of attainment of equilibrium (Joliff et al. 1992). Experimental data of trace element partitioning among biotite, muscovite and peraluminous silicic melt are scarce (Icenhower and London 1995). Calculated distribution coefficients for biotite-muscovite pairs are scarce, because equilibrium must be found (e.g., Albuquerque 1975, Bea et al. 1994). They must be compared with those derived from crystal melt distribution coefficients. Discrepances may be due to changes in the geochemical behaviour of trace elements and to the presence of accessory phases.

Trace element microanalyses of single crystals of micas in thin sections were determined by laser ablation coupled to an ICP-mass spectrometer (Bea et al. 1994) and microprobe techniques (Icenhower and London 1995). These methods are the best to be applied, because inclusions can have an important effect in trace element contents of micas (Bea et al. 1993). However bulk analyses of micas will retain their values for petrologic interpretations, if trace elements concentrated in inclusions identified microscopically are not taken into account (e.g., Neiva 1998; Tischendorf et al. 2001).

The evolution of trace elements in separated $\mathrm{Fe}^{2+}$-biotite, siderophyllite and primary muscovite and equilibrium-disequilibrium for trace elements between coexisting micas of nine peraluminous Hercynian granitic series of differentiation from northern and central Portugal are studied. The preference of trace elements either for biotite or muscovite are discussed and compared with studies of coexisting micas from granitic rocks. A few partition ratios are compared with those determined experimentally between biotite and muscovite from peraluminous melt (Icenhower and London 1995). The importance of micas in the behaviour of trace elements of granitic rocks during diffrentiation is also presented.

\section{Occurrence of micas}

The micas occur in peraluminous granitic rocks from eight Portuguese areas (Fig. 1) already studied petrologically and chemically by us. Two-mica granite has similar amounts of both micas, but biotite-muscovite granite contains more biotite than muscovite, while muscovite-biotite granite has more muscovite than biotite. The rocks range: 1a) from biotite-hornblende tonalite to biotite-muscovite granite at Rebordelo and 1b) from muscovite-biotite granite to muscovite granite at Ervedosa (Gomes 1996, Gomes and Neiva 2002) from two-mica granite to muscovite granite at Jales (Neiva and Gomes 1991); 3) from muscovite-biotite granite to muscovite granite at Alijó-Sanfins (Neiva 1973); 4) from two-mica granite to muscovite-biotite granite at Torra ão (Neiva 1998); 5) four muscovite-biotite granites at Paredes da Beira-Penedono (Silva and Neiva 1990); 6) from biotite-muscovite granodiorite to muscovite-biotite granite porphyry at Serra da Estrela (Neiva et al. 1987); 7) from biotite granite to biotite-muscovite granite at Carregal do Sal-Nelas-Lagares da Beira (Silva 1995, Silva and Neiva 2000); 8) from biotite-muscovite granite to muscovite-biotite granite at Penamacor-Monsanto (Neiva and Campos 1992). Not all of the granitic rock contain coexisting micas. 


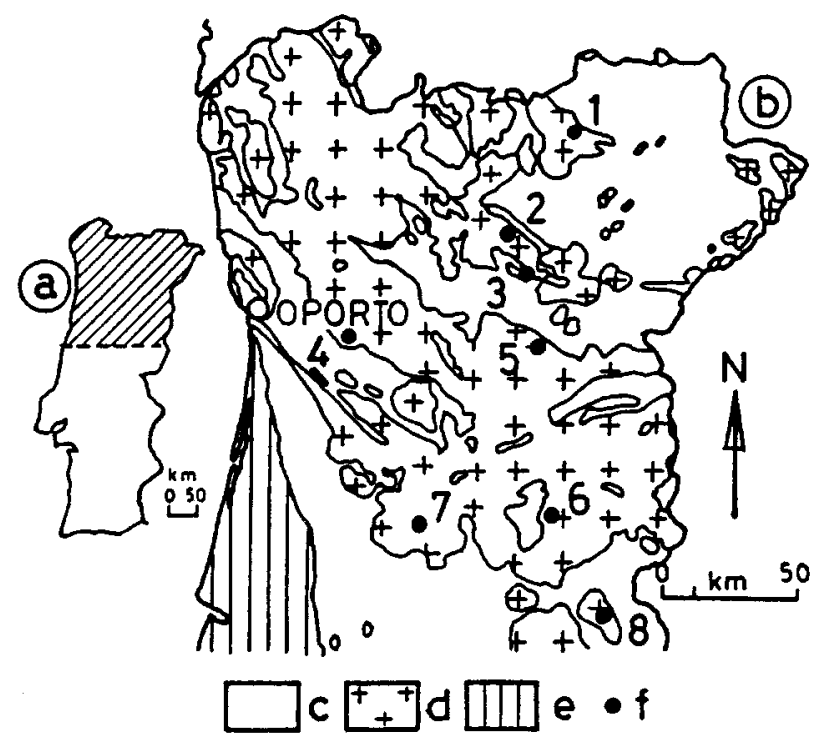

Fig. 1a. Location of Fig. 1b on the map of Portugal. b - Location of the selected areas; c - Preordovician metamorphic complexes, Paleozoic, some igneous and ultrabasic rocks; $d$ - Hercynian granitic rocks; e - Mesozoic and Cenozoic sedimentary rocks;

f - Areas: 1 - Rebordelo-Ervedosa; 2 - Jales; 3 - Alijó-Sanfins; 4 - Torrão; 5 - Paredes da Beira-Penedono; 6 - Serra da Estrela; 7 - Carregal do Sal-Nelas-Lagares da Beira; 8 - Penamacor-Monsanto.

The granitic rocks consist of quartz, K-feldspar, plagioclase, biotite, rare chlorite, muscovite, apatite, monazite, zircon, ilmenite and rutile. Tourmaline occurs in granitic rocks from Rebordelo, Ervedosa, Jales, Alijó-Sanfins, Serra da Estrela and Carregal do Sal-Nelas-Lagares da Beira. Andalusite and sillimanite were found in granites from Ervedosa, Jales, Torrão and Penamacor-Monsanto and sillimanite also occurs in granites and the granite porphyry from Serra da Estrela. Sphene was only found at Rebordelo, while garnet occurs only in the two-mica granite from Jales and cordierite appears only in the biotite granite from Carregal do Sal.

Average chemical compositions and trace elements of these granitic rocks are given in Tables 1, 2 and 3. The $\mathrm{Al}$ saturation index given by the molecular ratio $\mathrm{Al}_{2} \mathrm{O}_{3}$ / $\left(\mathrm{CaO}+\mathrm{Na}_{2} \mathrm{O}+\mathrm{K}_{2} \mathrm{O}\right)$ ranges between 1.02 and 1.39 .

\section{Analytical methods}

Biotite and muscovite were separated by magnetic separator and heavy liquids. A purity of about $99.8 \%$ was estimated by optical examination. The main contaminants are zircon, monazite and apatite. Several samples were selected from each granite. The trace elements were measured in the separated biotite and muscovite from each sample.

The major and trace elements of granitic rocks and trace elements of micas were mainly determined by X-ray fluorescence at Manchester University, U.K., using the method of Brown et al. (1973). Precisions for major elements and $\mathrm{Rb}$ were better than $1 \%$ and for trace elements about $\pm 4 \%$. The major elements of micas were determined using the modified Cambridge Geoscan elec- 
Table 1. Average chemical analyses in wt.\% and trace elements in ppm of peraluminous granitic rocks from northern Portugal.

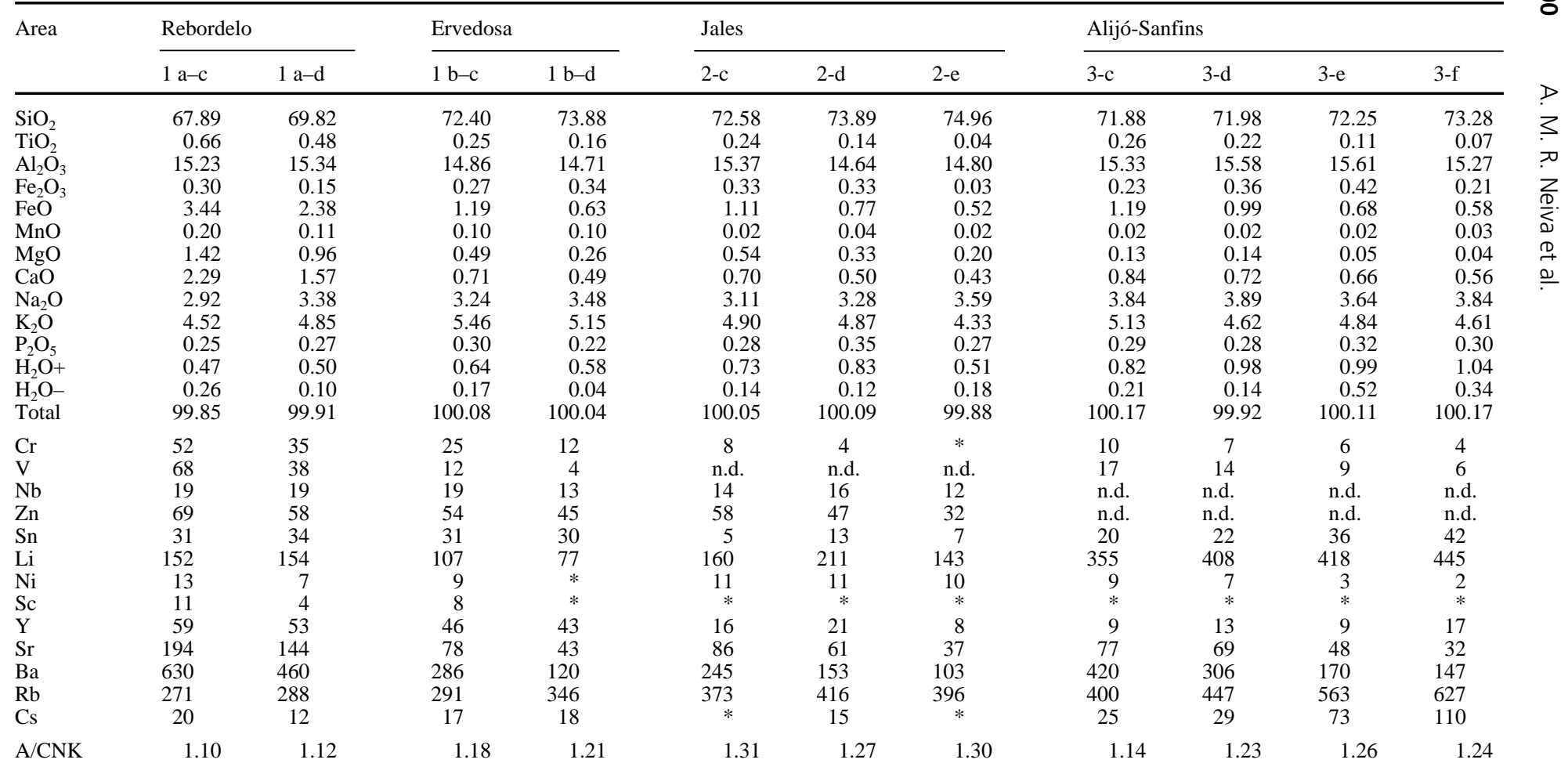

$1 \mathrm{a}-\mathrm{c}$ - fine- to medium-grained porphyritic biotite granodiorite; $1 \mathrm{a}-\mathrm{d}$ - medium-grained porphyritic biotite-muscovite granite; $1 \mathrm{~b}-\mathrm{c}-$ medium-grained slightly

porphyritic muscovite-biotite granite; $1 \mathrm{~b}-\mathrm{d}$ - medium- to fine-grained muscovite-biotite granite;
$2-\mathrm{c}-$ medium- to coarse-grained porphyritic seriate two-mica granite; 2 -d - coarse-grained slightly porphyritic muscovite-biotite granite; 2 -e - fine-grained muscovite granite;

3-c - coarse-grained gneissose porphyritic muscovite-biotite granite; 3-d - fine-grained gneissose porphyritic muscovite-biotite granites; 3-e - medium-grained muscovitebiotite granite; 3 - $\mathrm{f}$ - fine-grained feebly porphyritic muscovite-biotite granite

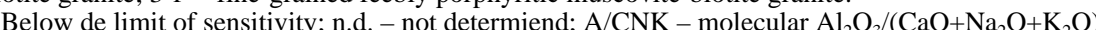


tron microprobe equipped with a Link Analytical energy-dispersive X-ray analyser at Manchester University.

$\mathrm{FeO}$ of rocks and micas were determined by titration with a standardised potassium permanganate solution, and $\mathrm{H}_{2} \mathrm{O}+$ was determined using a Penfield tube; both with the precision of $\pm 1 \%$. Total $\mathrm{Fe}_{2} \mathrm{O}_{3}$ of biotites and $\mathrm{Li}$ of rocks and micas were determined by atomic absorption, while $\mathrm{C} 1$ and $\mathrm{F}$ of micas were measured with selective ion electrodes, but all with the precision of $\pm 2 \%$.

However the major elements of granites and their micas from Alijó-Sanfins were determined by XRF, using the method of Norrish and Hutton (1969). The trace elements Cr, V, Sn, Li, Ni, Sr, Ba, $\mathrm{Rb}$ and $\mathrm{Cs}$ of rocks and micas and $\mathrm{Nb}, \mathrm{Zn}, \mathrm{Sc}$ and $\mathrm{Y}$ of rocks were measured by emission spec-

Table 2. Average chemical analyses in wt. $\%$ and trace elements in ppm of granites from northern Portugal.

\begin{tabular}{|c|c|c|c|c|c|c|}
\hline \multirow[t]{2}{*}{ Area } & \multicolumn{2}{|l|}{ Torrão } & \multicolumn{4}{|c|}{ Paredes da Beira-Penedono } \\
\hline & $\begin{array}{l}-c \\
4\end{array}$ & $4-d$ & $5-\mathrm{a}$ & $5-\mathrm{b}$ & $5-c$ & $5-d$ \\
\hline $\mathrm{SiO}_{2}$ & 71.51 & 72.18 & 72.34 & 72.82 & 73.56 & 73.90 \\
\hline $\mathrm{TiO}_{2}$ & 0.36 & 0.31 & 0.21 & 0.19 & 0.21 & 0.13 \\
\hline $\mathrm{Al}_{2} \mathrm{O}_{3}$ & 15.09 & 14.81 & 15.33 & 15.25 & 14.66 & 15.11 \\
\hline $\mathrm{Fe}_{2} \mathrm{O}_{3}$ & 0.12 & 0.12 & 0.48 & 0.39 & 0.45 & 0.27 \\
\hline $\mathrm{FeO}$ & 1.64 & 1.47 & 0.79 & 0.91 & 0.94 & 0.91 \\
\hline $\mathrm{MnO}$ & 0.10 & 0.10 & 0.05 & 0.05 & 0.05 & 0.05 \\
\hline $\mathrm{MgO}$ & 0.70 & 0.57 & 0.40 & 0.38 & 0.37 & 0.29 \\
\hline $\mathrm{CaO}$ & 0.98 & 0.81 & 0.46 & 0.43 & 0.53 & 0.35 \\
\hline $\mathrm{Na}_{2} \mathrm{O}$ & 3.65 & 3.68 & 2.65 & 3.03 & 3.16 & 3.00 \\
\hline $\mathrm{K}_{2} \mathrm{O}$ & 4.81 & 5.11 & 5.42 & 5.08 & 5.05 & 4.96 \\
\hline $\mathrm{P}_{2} \mathrm{O}_{5}$ & 0.25 & 0.32 & 0.34 & 0.32 & 0.40 & 0.26 \\
\hline $\mathrm{H}_{2} \mathrm{O}+$ & 0.70 & 0.47 & 1.19 & 0.89 & 0.52 & 0.40 \\
\hline $\mathrm{H}_{2} \mathrm{O}-$ & 0.07 & 0.04 & 0.26 & 0.26 & 0.09 & 0.28 \\
\hline Total & 99.98 & 99.99 & 99.92 & 100.00 & 99.99 & 99.91 \\
\hline $\mathrm{Cr}$ & 17 & 11 & 21 & 23 & 23 & 21 \\
\hline V & 24 & 17 & 8 & 11 & 13 & 8 \\
\hline $\mathrm{Nb}$ & 16 & 25 & 20 & 24 & 20 & 22 \\
\hline $\mathrm{Zn}$ & 78 & 67 & 58 & 71 & 91 & 64 \\
\hline $\mathrm{Sn}$ & $*$ & 7 & * & 5 & * & * \\
\hline $\mathrm{Li}$ & 67 & 82 & 108 & 174 & 234 & 201 \\
\hline $\mathrm{Ni}$ & $*$ & $*$ & 3 & 4 & 4 & 4 \\
\hline $\mathrm{Sc}$ & $*$ & $*$ & 6 & 5 & $*$ & 5 \\
\hline $\mathrm{Y}$ & 40 & 44 & 19 & 21 & 20 & 20 \\
\hline $\mathrm{Sr}$ & 215 & 123 & 84 & 62 & 56 & 46 \\
\hline $\mathrm{Ba}$ & 599 & 300 & 229 & 143 & 124 & 83 \\
\hline $\mathrm{Rb}$ & 260 & 374 & 305 & 383 & 484 & 484 \\
\hline Cs & n.d. & n.d. & 7 & 18 & 31 & 11 \\
\hline $\mathrm{A} / \mathrm{CNK}$ & 1.16 & 1.14 & 1.39 & 1.35 & 1.26 & 1.38 \\
\hline
\end{tabular}

4-c - medium- to fine-grained two-mica granite; 4-d - medium-grained porphyritic muscovitebiotite granite;

5-a - fine-grained gneissose porphyritic muscovite-biotite granite; 5-b - medium-grained gneissose seriate muscovite-biotite granite; 5 -c - medium-grained porphyritic muscovite-biotite granite; 5 - $\mathrm{d}$ medium-grained porphyritic muscovite-biotite granite.

*Below the limit of sensitivity; n.d. - not determined. 
troscopy with a precision of $\pm 20-25 \%$ at the University of Cambridge, U.K. (Neiva 1973). Nb, Zn, Sc and Y of micas from Alijó-Sanfins were determined with an Associated Electrical Industries Limited MS7 spark source mass spectrograph with a precision of $\pm 7 \%$ and the limit of detection of $0.01 \mathrm{ppm}$ at the University of Manchester (Neiva 1973).

Table 3. Average chemical analyses in wt.\% and trace elements in ppm of granitic rocks from central Portugal.

\begin{tabular}{|c|c|c|c|c|c|c|c|}
\hline \multirow[t]{2}{*}{ Area } & \multicolumn{3}{|c|}{ Serra da Estrela } & \multicolumn{2}{|c|}{$\begin{array}{l}\text { Carregal do Sal - } \\
\text { Nelas - } \\
\text { Lagares da Beira }\end{array}$} & \multicolumn{2}{|c|}{ Penamacor - Monsanto } \\
\hline & $6-c$ & $6-d$ & $6-e$ & $7-\mathrm{c}$ & $7-d$ & $8-\mathrm{c}$ & $8-d$ \\
\hline $\mathrm{SiO}_{2}$ & 74.32 & 73.91 & 75.97 & 71.21 & 73.35 & 73.52 & 75.04 \\
\hline $\mathrm{TiO}_{2}$ & 0.29 & 0.12 & 0.08 & 0.48 & 0.29 & 0.36 & 0.22 \\
\hline $\mathrm{Al}_{2} \mathrm{O}_{3}$ & 13.55 & 14.58 & 13.28 & 14.07 & 14.09 & 12.50 & 12.41 \\
\hline $\mathrm{Fe}_{2} \mathrm{O}_{3}$ & 0.22 & 0.49 & 0.52 & 0.27 & 0.10 & 0.36 & 0.36 \\
\hline $\mathrm{FeO}$ & 1.55 & 0.61 & 0.50 & 2.36 & 1.64 & 1.75 & 1.03 \\
\hline $\mathrm{MnO}$ & 0.06 & 0.06 & 0.06 & 0.03 & 0.04 & 0.03 & 0.02 \\
\hline $\mathrm{MgO}$ & 0.44 & 0.24 & 0.21 & 0.76 & 0.53 & 1.34 & 1.17 \\
\hline $\mathrm{CaO}$ & 0.71 & 0.47 & 0.30 & 1.20 & 0.97 & 0.74 & 0.55 \\
\hline $\mathrm{Na}_{2} \mathrm{O}$ & 3.24 & 3.19 & 3.20 & 2.89 & 3.01 & 3.70 & 3.85 \\
\hline $\mathrm{K}_{2} \mathrm{O}$ & 4.70 & 4.98 & 4.57 & 5.12 & 5.06 & 4.49 & 4.41 \\
\hline $\mathrm{P}_{2} \mathrm{O}_{5}$ & 0.28 & 0.24 & 0.22 & 0.27 & 0.20 & 0.56 & 0.41 \\
\hline $\mathrm{H}_{2} \mathrm{O}+$ & 0.59 & 0.99 & 1.01 & 0.94 & 0.58 & 0.65 & 0.50 \\
\hline $\mathrm{H}_{2} \mathrm{O}-$ & 0.05 & 0.17 & 0.14 & 0.05 & 0.04 & 0.08 & 0.02 \\
\hline Total & 100.00 & 100.05 & 100.06 & 99.65 & 99.90 & 100.08 & 99.99 \\
\hline $\mathrm{Cr}$ & 24 & 22 & 21 & 9 & 7 & 33 & 27 \\
\hline V & n.d. & n.d. & n.d. & 31 & 17 & 7 & 3 \\
\hline $\mathrm{Nb}$ & 10 & 6 & 5 & 25 & 31 & 9 & 12 \\
\hline $\mathrm{Zn}$ & 80 & 54 & 66 & 66 & 64 & 111 & 122 \\
\hline Sn & * & $*$ & $*$ & 22 & 36 & $*$ & 11 \\
\hline $\mathrm{Li}$ & 118 & 64 & 67 & 140 & 124 & 134 & 162 \\
\hline $\mathrm{Ni}$ & 7 & 10 & 9 & 17 & 18 & 7 & 6 \\
\hline $\mathrm{Sc}$ & 6 & 5 & 3 & 5 & $*$ & 4 & 4 \\
\hline $\mathrm{Y}$ & 45 & 45 & 36 & 43 & 31 & 26 & 27 \\
\hline $\mathrm{Sr}$ & 76 & 74 & 19 & 87 & 94 & 55 & 21 \\
\hline $\mathrm{Ba}$ & 202 & 146 & 5 & 302 & 368 & 214 & 75 \\
\hline $\mathrm{Rb}$ & 344 & 336 & 332 & 351 & 355 & 271 & 364 \\
\hline Cs & 5 & 5 & * & 20 & 18 & n.d. & n.d. \\
\hline $\mathrm{A} / \mathrm{CNK}$ & 1.16 & 1.27 & 1.24 & 1.13 & 1.16 & 1.02 & 1.03 \\
\hline
\end{tabular}

6-c - coarse-grained porphyritic biotite-muscovite granite; 6 -d - fine- to medium-grained slightly porphyritic muscovite-biotite granite; 6-e - granite porphyry;

7-c - coarse- to very coarse-grained porphyritic biotite granite; 7-d - medium- to coarse-grained porphyritic biotite-muscovite granite;

8-c - coarse- to medium-grained porphyritic biotite-muscovite granite; 8-d - coarse-grained porphyritic muscovite-biotite granite.

n.d. - not determined; * below the limit of sensitivity. 


\section{Chemical composition of micas}

Major and trace element analyses of coexisting biotite and muscovite from Portuguese peraluminous granitic differentiation series are given in Tables 4, 5, 6, 7, 8 and 9. The biotites are mainly $\mathrm{Fe}^{2+}$-biotite (Figs. 2a, b), but a few from Paredes da Beira-Penedono and Serra da Estrela have a composition ranging from $\mathrm{Fe}^{2+}$-biotite to siderophyllite (Fig. 2b) according to the nomenclature of Foster (1960). The muscovites correspond to compositions of primary muscovite (Miller et al. 1981; Monier et al. 1984) as shown in Fig. 3 and contain a significant celadonitic component.
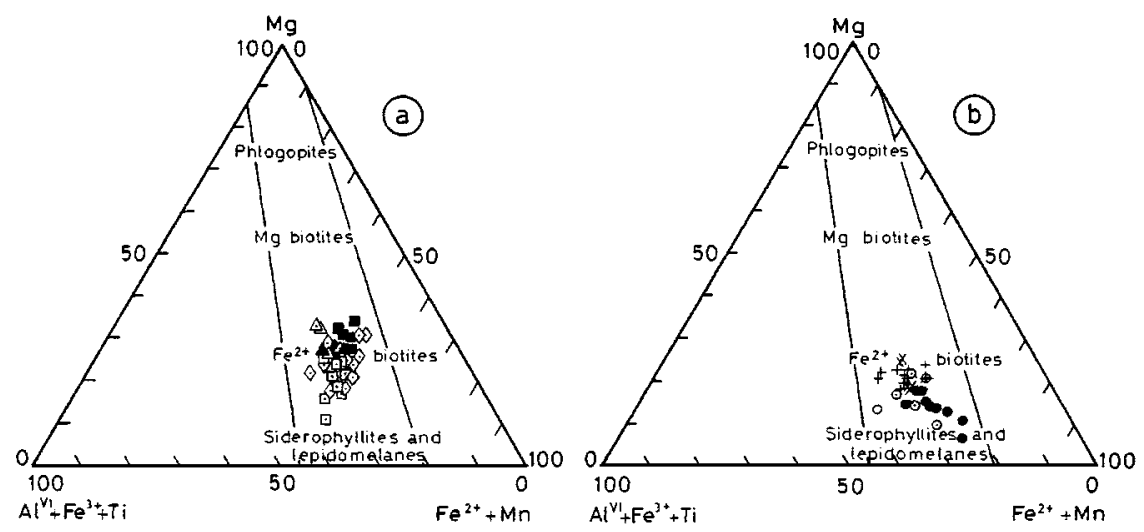

Fig. 2. Compositions of biotite from Portuguese granitic differentiation series.

a. $\square$ Rebordelo, $\diamond$ Ervedosa, $\square$ Jales, $\Delta$ Alijó-Sanfins, $\triangle$ Torrão;

b. $\odot$ Paredes da Beira-Penedono, Serra da Estrela, + Carregal do Sal-Nelas-Lagares da Beira, $\times$ Penamacor-Monsanto.

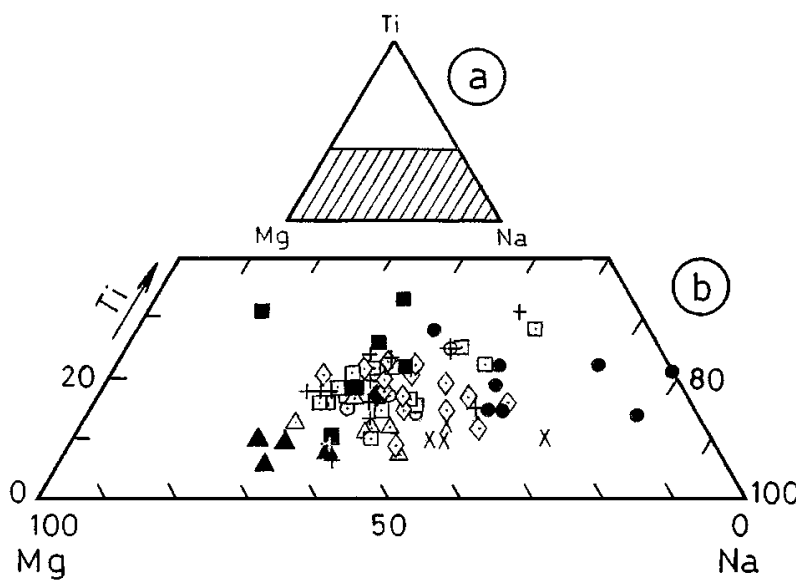

Fig. 3. Compositions of muscovite from Portuguese granitic differentiation series. Symbols as in Fig. 2. 


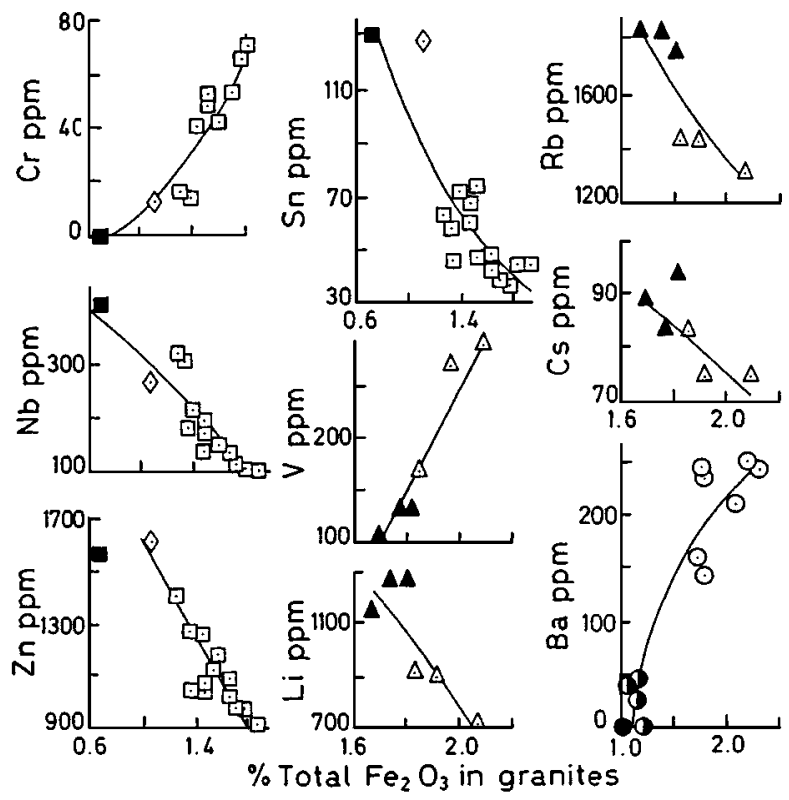

Fig. 4. Variation diagrams of trace elements of biotite from Portuguese granitic series. Symbols: $\square$ two-mica granite, $\diamond$ muscovite-biotite granite, $\square$ muscovite granite from Jales; $\triangleleft$ twomica granite, $\boldsymbol{\Delta}$ muscovite-biotite granite from Torrão; $\odot$ biotite-muscovite granite, $\bigcirc$ muscovitebiotite granite, $\bigcirc$ granite porphyry from Serra da Estrela.

Data of bulk trace elements were determined on mineral separates. However contents of $\mathrm{Zr}, \mathrm{U}$, Th and REE (mainly $\mathrm{La}, \mathrm{Ce}, \mathrm{Nd}$ ) are constituents of inclusions and therefore are not considered. The degree of fractionation of granitic melt controls the chemical composition of micas studied, particularly the behaviour of trace elements. Generally $\mathrm{Cr}, \mathrm{V}, \mathrm{Sc}$, $\mathrm{Ba}$ contents decrease and $\mathrm{Nb}, \mathrm{Zn}, \mathrm{Sn}, \mathrm{Li}, \mathrm{Rb}, \mathrm{Cs}$ contents increase in both biotite and muscovite, but $\mathrm{Ni}$ content also decreases and $\mathrm{Y}$ content increases in biotite with decreasing total $\mathrm{Fe}_{2} \mathrm{O}_{3}$ in the granitic rocks within each Portuguese series studied. The behaviours of some trace elements are shown, e.g., $\mathrm{Cr}, \mathrm{Nb}, \mathrm{Zn}$ and $\mathrm{Sn}$ in biotite from the Jales series; V, Li, Rb and Cs in biotite from the Torrão series and $\mathrm{Ba}$ in biotite from the Serra da Estrela series (Fig. 4); Cr, Nb, Zn, Sn and Ba in muscovite from Jales series; V, $\mathrm{Li}, \mathrm{Rb}$ and $\mathrm{Cs}$ in muscovite from Torrão series (Fig. 5).

\section{Equilibrium-disequilibrium between coexisting micas}

The correlations between coexisting biotite and muscovite concentrations were verified through the Pearson's coefficients. They are significant with a probability of $>0.95$. Correlations between coexisting micas were found for ten trace elements in a variable number of differentiation series: $\mathrm{Cr}$ in series 1a, 2, 4 and 6; $\mathrm{V}$ in series $1 \mathrm{a}$ and 4; $\mathrm{Nb}$ in 


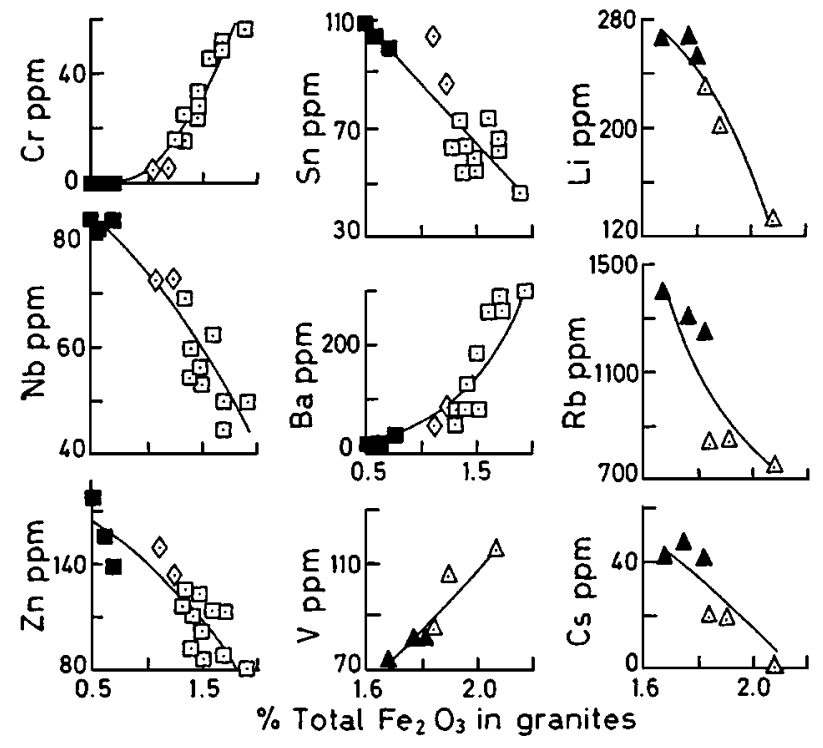

Fig. 5. Variation diagrams of trace elements of muscovite from Portuguese granitic series. Symbols as in Fig. 4.

series 1a and 2; Cs in series 2, 3 and 6; $\mathrm{Li}$ in series $1 \mathrm{a}, 1 \mathrm{~b}, 2,4$ and 7; $\mathrm{Rb}$ in series 1a, $1 \mathrm{~b}$, 2, 4 and 7 (Fig. 6); $\mathrm{Zn}$ in series 2; $\mathrm{Sn}$ in series 6; $\mathrm{Y}$ in series 4; Ba in series 4 (Fig. 7). So the series 2 (Jales) and series 4 (Torrão) have the highest number of correlations for trace elements between coexisting micas ( 6 for each series) followed by the series 1a (Rebordelo) with five trace elements.

Only the distribution of $\mathrm{Cr}$ in the biotite/muscovite pairs of series 2 and 4 and of $\mathrm{Cs}$ in these pairs for series 6 pass through the origin (Fig. 6) and represent equilibrium between coexisting micas for these trace elements. Biotite and muscovite occur in independent flakes, but are also intergrown in other flakes, as observed microscopically in all samples suggesting that they grew simultaneously.

In most of the series, the regression lines do not pass through the origin (Figs. 6 and 7), which can be related to solid-liquid reequilibration during the late-magmatic evolution. Furthermore, the variations in composition and temperature are not enough great within each series, except in series 1a, to explain that most of the correlations do not pass through the origin (Icenhower and London 1995). Disequilibrium predominates over equilibrium on the distribution of trace elements between coexisting micas. Trace elements were determined on mica separates, but this technique may not be responsible for the general disequilibrium found, because a similar procedure was applied in Viseu area, central Portugal and equilibrium was found between coexisting micas from two granitic suites (Neves 1997).

Generally the same correlation between coexisting micas shows distinct slopes for different differentiation series (Fig. 6), which would be attributed to different degrees of fractional crystallization if the regression lines were passing through the origin. Therefore they are also probably due to solid-liquid reequilibration during late-magmatic evolution. 


\section{Distribution coefficients}

Distribution coefficients can only be calculated if a linear correlation was found for a trace element between two coexisting minerals. If the regression line does not pass through the origin, the distribution coefficient is expressed as a linear funktion. If the regression lines pass through the origin, partition ratios are calculated dividing the concentration of any trace element in biotite by its content in the coexisting muscovite (Beattie et al. 1993). $\mathrm{D}(\mathrm{M})^{\mathrm{Bt} / \mathrm{Ms}}$ where $\mathrm{D}, \mathrm{Bt}, \mathrm{Ms}$ and $\mathrm{M}$ represent the partition ratio, biotite, muscovite and the trace element of interest respectively. Calculated distribution coefficients for trace elements analyzed on separates of coexisting biotite and muscovite from different Portuguese granitic series are given in Table 10. Partition ratios could only be calculated for $\mathrm{Cr}$ of series 2 (Jales) and series 4 (Torrão) and for Cs of series 6 (Serra da Estrela), because only for them regression lines pass through the origin.
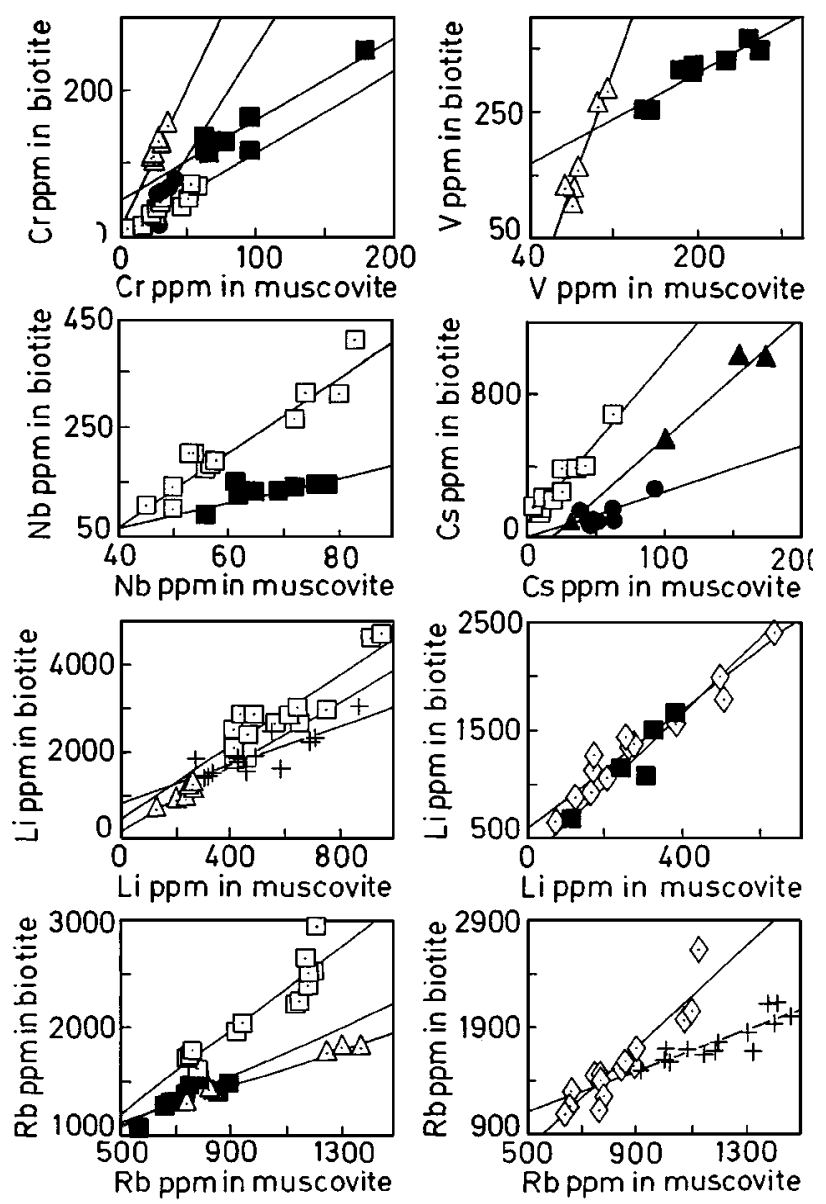

Fig. 6. Correlations of $\mathrm{Cr}, \mathrm{V}, \mathrm{Nb}, \mathrm{Cs}, \mathrm{Li}$ and $\mathrm{Rb}$ between coexisting biotite and muscovite from some Portuguese granitic differentiation series.

Symbols: $\square$ Rebordelo - 1a, $\diamond$ Ervedosa - 1b, $\square$ Jales - 2, $\Delta$ Alijó-Sanfins -3 , $\triangleleft$ Torrão - 4, - Serra da Estrela - 6, + Carregal do Sal-Nelas-Lagares da Beira - 7. Numbers of the series. 

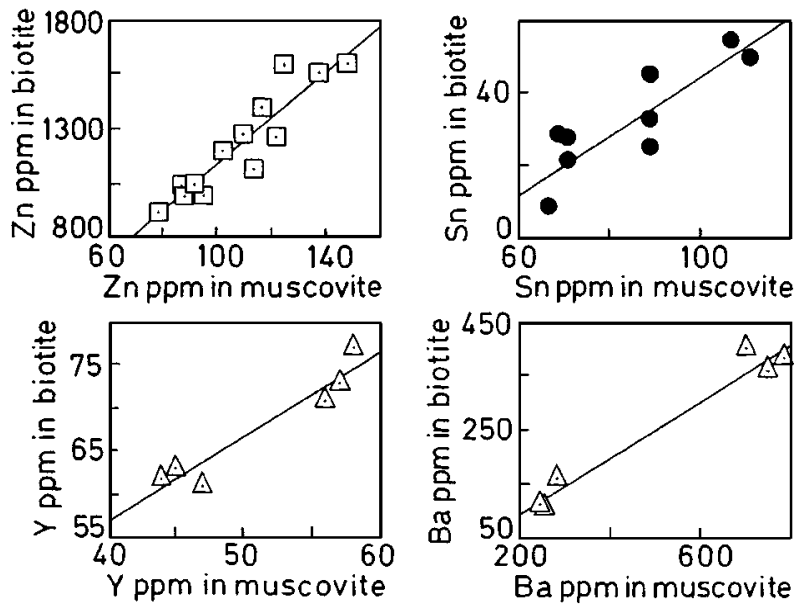

Fig. 7. Correlations of $\mathrm{Zn}, \mathrm{Sn}, \mathrm{Y}$ and Ba between coexisting micas from Portuguese granitic differentiation series.

Symbols: $\square$ Jales -2 , $\odot$ Serra da Estrela $-6, \triangle$ Torrão -4 . Numbers of the series.

Table 4. Average chemical analyses in wt. $\%$ and trace elements in ppm of coexisting biotite and muscovite of peraluminous granitic rocks from Rebordelo and Ervedosa, northern Portugal.

\begin{tabular}{|c|c|c|c|c|c|c|c|c|}
\hline & \multicolumn{4}{|c|}{ Rebordelo } & \multicolumn{4}{|c|}{ Ervedosa } \\
\hline & $\begin{array}{l}\text { Biotite } \\
1 \text { a-c }\end{array}$ & $\begin{array}{l}\text { Muscovite } \\
1 \text { a-c }\end{array}$ & $\begin{array}{l}\text { Biotite } \\
1 \text { a-d }\end{array}$ & $\begin{array}{l}\text { Muscovite } \\
1 \text { a-d }\end{array}$ & $\begin{array}{l}\text { Biotite } \\
1 \mathrm{~b}-\mathrm{c}\end{array}$ & $\begin{array}{l}\text { Muscovite } \\
1 \mathrm{~b}-\mathrm{c}\end{array}$ & $\begin{array}{l}\text { Biotite } \\
1 \text { b-d }\end{array}$ & $\begin{array}{l}\text { Muscovite } \\
1 \text { b-d }\end{array}$ \\
\hline $\mathrm{SiO}_{2}$ & 36.00 & 46.31 & 35.42 & 45.46 & 35.40 & 45.87 & 36.13 & 46.59 \\
\hline $\mathrm{TiO}_{2}$ & 2.94 & 1.23 & 2.55 & 1.10 & 2.69 & 0.63 & 2.18 & 1.01 \\
\hline $\mathrm{Al}_{2} \mathrm{O}_{3}$ & 18.05 & 33.46 & 18.82 & 34.75 & 19.05 & 35.32 & 20.48 & 34.49 \\
\hline $\mathrm{Fe}_{2} \mathrm{O}_{3}$ & 1.71 & 0.47 & 2.06 & 0.43 & 2.36 & 0.50 & 3.33 & 0.54 \\
\hline $\mathrm{FeO}$ & 20.25 & 0.98 & 20.56 & 0.88 & 21.09 & 0.84 & 20.22 & 0.95 \\
\hline $\mathrm{MnO}$ & 0.27 & 0.01 & 0.23 & 0.03 & 0.19 & 0.02 & 0.23 & - \\
\hline $\mathrm{MgO}$ & 7.24 & 1.24 & 7.30 & 0.80 & 6.38 & 0.71 & 4.44 & 0.85 \\
\hline $\mathrm{CaO}$ & 0.09 & 0.01 & 0.02 & 0.01 & 0.03 & 0.03 & 0.03 & - \\
\hline $\mathrm{Na}_{2} \mathrm{O}$ & 0.20 & 0.43 & 0.39 & 0.62 & 0.45 & 0.63 & 0.46 & 0.76 \\
\hline $\mathrm{K}_{2} \mathrm{O}$ & 9.63 & 10.50 & 9.37 & 10.28 & 9.32 & 10.34 & 9.11 & 10.25 \\
\hline $\mathrm{Cl}$ & 0.06 & 0.03 & 0.05 & 0.03 & 0.05 & 0.03 & 0.04 & 0.03 \\
\hline \multirow[t]{2}{*}{$\mathrm{F}$} & 0.35 & 0.13 & 0.37 & 0.17 & 0.33 & 0.14 & 0.45 & 0.25 \\
\hline & 96.79 & 94.80 & 97.14 & 94.56 & 97.34 & 95.06 & 97.10 & 95.72 \\
\hline $\mathrm{O} \equiv \mathrm{Cl}$ & 0.01 & 0.01 & 0.01 & 0.01 & 0.01 & 0.01 & 0.01 & 0.01 \\
\hline $\mathrm{O} \equiv \mathrm{F}$ & 0.15 & 0.05 & 0.16 & 0.07 & 0.14 & 0.06 & 0.19 & 0.11 \\
\hline Total & 96.63 & 94.74 & 96.97 & 94.48 & 97.19 & 94.99 & 96.90 & 95.60 \\
\hline $\mathrm{Cr}$ & 188 & 137 & 134 & 71 & 101 & 31 & 59 & 19 \\
\hline $\mathrm{V}$ & 360 & 255 & 301 & 185 & 175 & 67 & 104 & 51 \\
\hline $\mathrm{Nb}$ & 107 & 59 & 852 & 70 & 207 & 76 & 311 & 103 \\
\hline $\mathrm{Zn}$ & 421 & 51 & 576 & 90 & 851 & 73 & 1170 & 117 \\
\hline $\mathrm{Sn}$ & 130 & 159 & 145 & 165 & 137 & 113 & 258 & 132 \\
\hline $\mathrm{Li}$ & 1100 & 305 & 1266 & 273 & 1378 & 266 & 2313 & 400 \\
\hline $\mathrm{Ni}$ & 92 & 10 & 77 & 14 & 67 & 11 & 76 & 16 \\
\hline $\mathrm{Sc}$ & 37 & 58 & 27 & 55 & 10 & 17 & 3 & 13 \\
\hline Y & 71 & 50 & 72 & 45 & 85 & 48 & 90 & 56 \\
\hline $\mathrm{Sr}$ & 23 & 35 & 21 & 30 & 20 & 24 & 21 & 21 \\
\hline $\mathrm{Ba}$ & 418 & 598 & 81 & 381 & * & 181 & $*$ & 56 \\
\hline $\mathrm{Rb}$ & 1227 & 654 & 1406 & 773 & 1379 & 799 & 2296 & 1104 \\
\hline $\mathrm{Cs}$ & 70 & 12 & 103 & 16 & 127 & 16 & 393 & 15 \\
\hline
\end{tabular}

Column headings as in Table 1. - not detected; * below the limit of sensitivity. 
Table 5. Average chemical analyses in wt.\% and trace elements in ppm of coexisting biotite and muscovite of peraluminous granitic rocks from Jales, northern Portugal.

\begin{tabular}{|c|c|c|c|c|c|c|}
\hline & $\begin{array}{l}\text { Biotite } \\
2-c\end{array}$ & $\begin{array}{l}\text { Muscovite } \\
2 \text {-c }\end{array}$ & $\begin{array}{l}\text { Biotite } \\
2-d\end{array}$ & $\begin{array}{l}\text { Muscovite } \\
2-d\end{array}$ & $\begin{array}{l}\text { Biotite } \\
2-\mathrm{e}\end{array}$ & $\begin{array}{l}\text { Muscovite } \\
2-\mathrm{e}\end{array}$ \\
\hline $\mathrm{SiO}_{2}$ & 35.93 & 46.65 & 36.35 & 46.07 & 35.48 & 46.41 \\
\hline $\mathrm{TiO}_{2}$ & 2.58 & 0.74 & 2.35 & 0.51 & 1.55 & 0.27 \\
\hline $\mathrm{Al}_{2} \mathrm{O}_{3}$ & 19.88 & 35.15 & 21.41 & 34.95 & 22.37 & 35.34 \\
\hline $\mathrm{Fe}_{2} \mathrm{O}_{3}$ & 1.64 & 0.27 & 1.49 & 0.40 & 2.83 & 0.30 \\
\hline $\mathrm{FeO}$ & 20.41 & 1.30 & 20.85 & 1.60 & 19.99 & 1.93 \\
\hline $\mathrm{MnO}$ & 0.46 & 0.02 & 0.53 & 0.04 & 1.33 & 0.11 \\
\hline $\mathrm{MgO}$ & 5.52 & 0.77 & 3.67 & 0.87 & 2.37 & 0.68 \\
\hline $\mathrm{CaO}$ & 0.01 & 0.01 & 0.01 & - & - & - \\
\hline $\mathrm{Na}_{2} \mathrm{O}$ & 0.09 & 0.55 & 0.07 & 0.56 & 0.05 & 0.40 \\
\hline $\mathrm{K}_{2} \mathrm{O}$ & 9.27 & 10.12 & 9.09 & 10.28 & 8.93 & 10.21 \\
\hline $\mathrm{Cl}$ & 0.03 & - & 0.02 & - & 0.03 & - \\
\hline \multirow[t]{2}{*}{$\mathrm{F}$} & 0.71 & 0.36 & 0.79 & 0.52 & 0.54 & 0.30 \\
\hline & 96.53 & 95.94 & 96.63 & 95.80 & 95.47 & 95.95 \\
\hline $\mathrm{O} \equiv \mathrm{Cl}$ & 0.01 & - & - & - & 0.01 & - \\
\hline $\mathrm{O} \equiv \mathrm{F}$ & 0.30 & 0.15 & 0.33 & 0.22 & 0.23 & 0.13 \\
\hline Total & 96.22 & 95.79 & 96.30 & 95.58 & 95.23 & 95.82 \\
\hline $\mathrm{Cr}$ & 43 & 34 & 13 & 5 & $*$ & $*$ \\
\hline V & n.d. & n.d. & n.d. & n.d. & n.d. & n.d. \\
\hline $\mathrm{Nb}$ & 191 & 58 & 270 & 72 & 410 & 83 \\
\hline $\mathrm{Zn}$ & 1167 & 103 & 1595 & 141 & 1560 & 157 \\
\hline Sn & 54 & 60 & 129 & 96 & 130 & 103 \\
\hline $\mathrm{Li}$ & 2614 & 569 & 4617 & 910 & 4731 & 941 \\
\hline $\mathrm{Ni}$ & 57 & 17 & 25 & 10 & 9 & 19 \\
\hline Sc & 8 & 24 & $*$ & 16 & $*$ & 9 \\
\hline Y & 64 & 38 & 104 & 9 & 58 & 29 \\
\hline $\mathrm{Sr}$ & n.d. & n.d. & n.d. & n.d. & n.d. & n.d. \\
\hline $\mathrm{Ba}$ & 159 & 158 & 57 & 65 & * & 15 \\
\hline $\mathrm{Rb}$ & 2085 & 978 & 2520 & 1178 & 2933 & 1281 \\
\hline Cs & 253 & 16 & 696 & 59 & 770 & 38 \\
\hline
\end{tabular}

Column headings as in Table 1. - not detected; * below the limit of sensitivity; n.d. - not determined.

Most trace elements have a higher concentration in biotite than in coexisting muscovite (Tables 4, 5, 6, 7, 8 and 9), but Sn, Sc and Ba show preference for muscovite (e.g., Albuquerque 1975), which cannot be the result of late muscovite crystallization from an enriched residual melt, because this melt would have been impoverished in Sc and $\mathrm{Ba}$ as shown by the decrease in $\mathrm{Ba}$ content in biotite from Serra da Estrela series (Fig. 4) and muscovite from Jales series (Fig. 5).

$\mathrm{Cr}, \mathrm{V}, \mathrm{Nb}, \mathrm{Zn}, \mathrm{Sn}, \mathrm{Li}, \mathrm{Ni}$ and $\mathrm{Sc}$ seem likely to substitute in octahedral sites in micas. $\mathrm{Cr}^{3+}(6.3 \mathrm{~nm})$ and $\mathrm{V}^{3+}(7.4 \mathrm{~nm})$ will substitute for $\mathrm{Fe}^{3+}(6.4 \mathrm{~nm}) ; \mathrm{Li}^{+}(6.8 \mathrm{~nm})$ will replace $\mathrm{Mg}^{2+}(6.6 \mathrm{~nm})$, but requires a coupled substitution (Foster 1960); $\mathrm{Ni}^{2+}(6.9 \mathrm{~nm})$ will replace $\mathrm{Mg}^{2+}$; and $\mathrm{Zn}^{2+}(7.4 \mathrm{~nm})$ and $\mathrm{Sc}^{2+}(8.1 \mathrm{~nm})$ will substitute for $\mathrm{Fe}^{2+}(7.4 \mathrm{~nm})$. These trace elements replace major elements which are more abundant in biotite than in muscovite (Tables 4 to 9). Consequently these elements are generally more concentrated in biotite than in coexisting muscovite. Partition ratio for $\mathrm{Cr}$ in series 4 is higher by two orders of magnitude than in series 2 (Table 10), but similar to that found by Neves (1997). In biotite/muscovite pairs commonly $\mathrm{Cr}$ and $\mathrm{V}$ prefer biotite (Albuquerque 1975; Neiva 1977; Neves 1997).

Rare data were found in the literature on $\mathrm{Nb}$ and $\mathrm{Zn}$ of coexisting biotite and muscovite from granitic rocks, but they prefer biotite rather than coexisting muscovite (Jolliff et al. 1992; Neves 1977) as in this study. 
Table 6. Average chemical analyses in wt.\% and trace elements in ppm of coexisting biotite and muscovite of peraluminous granitic rocks from Alijó-Sanfins, northern Portugal.

\begin{tabular}{|c|c|c|c|c|c|c|c|c|}
\hline & $\begin{array}{l}\text { Biotite } \\
3-c\end{array}$ & $\begin{array}{l}\text { Muscovite } \\
\text { 3-c }\end{array}$ & $\begin{array}{l}\text { Biotite } \\
3-d\end{array}$ & $\begin{array}{l}\text { Muscovite } \\
\text { 3-d }\end{array}$ & $\begin{array}{l}\text { Biotite } \\
3-\mathrm{e}\end{array}$ & $\begin{array}{l}\text { Muscovite } \\
3 \text {-e }\end{array}$ & $\begin{array}{l}\text { Biotite } \\
3-f\end{array}$ & $\begin{array}{l}\text { Muscovite } \\
\text { 3-f }\end{array}$ \\
\hline $\mathrm{SiO}_{2}$ & 34.63 & 45.33 & 34.09 & 45.60 & 35.45 & 44.56 & 35.17 & 45.72 \\
\hline $\mathrm{TiO}_{2}$ & 2.41 & 0.62 & 2.45 & 0.42 & 2.08 & 0.40 & 1.70 & 0.26 \\
\hline $\mathrm{Al}_{2} \mathrm{O}_{3}$ & 19.69 & 34.00 & 20.62 & 34.25 & 20.34 & 33.26 & 21.49 & 33.73 \\
\hline $\mathrm{Fe}_{2} \mathrm{O}_{3}$ & 1.52 & - & 2.29 & 0.76 & 2.69 & 0.48 & 2.54 & - \\
\hline $\mathrm{FeO}$ & 19.81 & 1.75 & 19.37 & 1.62 & 20.83 & 2.41 & 19.58 & 3.45 \\
\hline $\mathrm{MnO}$ & 0.46 & 0.04 & 0.48 & 0.04 & 0.49 & 0.05 & 0.95 & 0.10 \\
\hline $\mathrm{MgO}$ & 6.57 & 1.97 & 6.65 & 1.38 & 5.01 & 2.16 & 4.95 & 1.49 \\
\hline $\mathrm{CaO}$ & 1.61 & 0.63 & 0.51 & - & - & - & - & - \\
\hline $\mathrm{Na}_{2} \mathrm{O}$ & 0.22 & 0.61 & 0.12 & 0.71 & 0.22 & 0.75 & 0.19 & 0.54 \\
\hline $\mathrm{K}_{2} \mathrm{O}$ & 8.73 & 10.32 & 9.04 & 10.58 & 9.10 & 10.08 & 8.97 & 10.27 \\
\hline $\mathrm{Cl}$ & - & 0.06 & 0.06 & 0.08 & 0.09 & 0.10 & 0.11 & 0.11 \\
\hline \multirow[t]{2}{*}{$\mathrm{F}$} & - & 0.02 & 0.14 & 0.09 & 0.37 & 0.31 & 0.60 & 0.27 \\
\hline & 95.65 & 95.35 & 95.82 & 95.53 & 96.67 & 94.56 & 96.25 & 95.94 \\
\hline $\mathrm{O} \equiv \mathrm{Cl}$ & - & 0.01 & 0.01 & 0.02 & 0.02 & 0.02 & 0.02 & 0.02 \\
\hline $\mathrm{O} \equiv \mathrm{F}$ & - & 0.01 & 0.06 & 0.04 & 0.16 & 0.13 & 0.25 & 0.11 \\
\hline Total & 95.65 & 95.33 & 95.75 & 95.47 & 96.49 & 94.41 & 95.98 & 95.81 \\
\hline $\mathrm{Cr}$ & 37 & 13 & 48 & 6 & 23 & 5 & 17 & 5 \\
\hline V & 48 & $*$ & 48 & $*$ & $*$ & $*$ & * & $*$ \\
\hline $\mathrm{Nb}$ & 71 & 29 & 91 & 32 & 133 & 36 & 362 & 39 \\
\hline $\mathrm{Zn}$ & 242 & 58 & 250 & 186 & 359 & 277 & 543 & 380 \\
\hline $\mathrm{Sn}$ & 100 & 100 & 100 & 100 & 140 & 207 & 140 & 205 \\
\hline $\mathrm{Li}$ & 3850 & 500 & 3900 & 800 & 4000 & 1717 & 6000 & 2100 \\
\hline $\mathrm{Ni}$ & 43 & 2 & 37 & 2 & 13 & 2 & 8 & 2 \\
\hline $\mathrm{Sc}$ & 7 & 15 & 6 & 8 & 2 & 7 & 1 & 2 \\
\hline Y & 0.50 & 0.45 & 0.60 & 0.07 & 0.70 & 0.05 & 0.80 & 0.64 \\
\hline $\mathrm{Sr}$ & $*$ & * & $*$ & * & $*$ & $*$ & $*$ & $*$ \\
\hline $\mathrm{Ba}$ & 55 & 100 & 40 & 100 & 40 & 72 & 55 & 60 \\
\hline $\mathrm{Rb}$ & 2200 & 900 & 1360 & 960 & 2600 & 1113 & 1800 & 1300 \\
\hline $\mathrm{Cs}$ & 1000 & 32 & 550 & 100 & 1000 & 153 & 1000 & 173 \\
\hline
\end{tabular}

Column headings as in Table 1. - not detected; * below the limit of sensitivity.

Li is more concentrated in biotite than in coexisting muscovite (Tables 4 to 9) as found by Carron and Lagache (1972), Albuquerque (1975), Kretz et al. (1989), Jolliff et al. (1992), Bea et al. (1994) and Neves (1997).

$\mathrm{Sn}$ in biotite shows a strong resemblance to the behaviour of $\mathrm{Fe}^{2+}, \mathrm{Fe}^{3+}$ and $\mathrm{Ti}$ and is positively correlated with $\mathrm{Li}$ (e.g., Hesp 1971; Neiva 1976). Sn in muscovite is negatively correlated with $\mathrm{Ti}, \mathrm{Mg}$ and positively with $\mathrm{F}, \mathrm{Li}$ and $\mathrm{Rb}$ (Neiva 1977). In general, muscovite has a higher Sn content than coexisting biotite (Neiva 1984), as in the Pedrobernado pluton, central Spain (Bea et al. 1994) and in the granites of Viseu region, central Portugal (Neves 1997). However in the tin-bearing granites from Ervedosa, $\mathrm{Sn}$ is preferentially concentrated in biotite compared with coexisting muscovite (Table 4).

The data available on $\mathrm{Sr}$ for coexisting biotite and muscovite is only for five series (Tables 4, 7 and 8) and muscovite has a higher Sr content than coexisting biotite. The experimental data on element partitioning among biotite, muscovite and melt (Icenhower and London 1995) and the data on coexisting micas from granitic rocks (Jolliff et al., 1992; Neves 1997) support this finding. Sr has a radius $(11.2 \mathrm{~nm})$ closer to that of $\mathrm{Ca}^{2+}$ $(9.9 \mathrm{~nm})$ than that of $\mathrm{K}^{+}(13.3 \mathrm{~nm})$, but Ca was rarely detected in both micas. However, $\mathrm{Y}$ $(9.2 \mathrm{~nm})$ probably replaces $\mathrm{Ca}^{2+}$, but it is partitioned preferentially into biotite compared with coexisting muscovite (Tables 4-9). 
Table 7. Chemical analyses in wt.\% and trace elements in ppm of coexisting biotite and muscovite of granites from Torrão and Paredes da Beira - Penedono, northern Portugal.

\begin{tabular}{|c|c|c|c|c|c|c|c|c|c|c|c|c|}
\hline & \multicolumn{4}{|l|}{ Torrão } & \multicolumn{8}{|c|}{ Paredes da Beira - Penedono } \\
\hline & $\begin{array}{l}\text { Biotite } \\
\text { 4-c }\end{array}$ & $\begin{array}{l}\text { Muscovite } \\
\text { 4-c }\end{array}$ & $\begin{array}{l}\text { Biotite } \\
\text { 4-d }\end{array}$ & $\begin{array}{l}\text { Muscovite } \\
\text { 4-d }\end{array}$ & $\begin{array}{l}\text { Biotite } \\
5-\mathrm{a}\end{array}$ & $\begin{array}{l}\text { Muscovite } \\
\text { 5-a }\end{array}$ & $\begin{array}{l}\text { Biotite } \\
\text { 5-b }\end{array}$ & $\begin{array}{l}\text { Muscovite } \\
\text { 5-b }\end{array}$ & $\begin{array}{l}\text { Biotite } \\
\text { 5-c }\end{array}$ & $\begin{array}{l}\text { Muscovite } \\
\text { 5-c }\end{array}$ & $\begin{array}{l}\text { Biotite } \\
\text { 5-d }\end{array}$ & $\begin{array}{l}\text { Muscovite } \\
\text { 5-d }\end{array}$ \\
\hline $\mathrm{SiO}_{2}$ & 35.09 & 46.07 & 34.99 & 45.77 & 35.39 & 46.68 & 35.89 & 46.21 & 37.41 & 46.03 & 35.90 & 46.59 \\
\hline $\mathrm{TiO}_{2}$ & 2.71 & 0.69 & 2.53 & 0.60 & 2.53 & 0.75 & 2.28 & 0.50 & 2.42 & 0.53 & 2.44 & 0.48 \\
\hline $\mathrm{Al}_{2} \mathrm{O}_{3}$ & 19.25 & 35.41 & 19.57 & 35.40 & 19.12 & 34.53 & 19.68 & 33.89 & 19.61 & 33.43 & 19.80 & 33.21 \\
\hline $\mathrm{Fe}_{2} \mathrm{O}_{3}$ & 3.43 & 0.13 & 3.47 & 0.20 & 3.08 & 0.68 & 1.93 & 0.84 & 0.27 & 0.53 & 0.49 & 0.71 \\
\hline $\mathrm{FeO}$ & 17.28 & 1.14 & 18.93 & 1.33 & 20.73 & 0.97 & 21.68 & 1.76 & 22.90 & 2.77 & 24.88 & 2.20 \\
\hline $\mathrm{MnO}$ & 0.22 & 0.02 & 0.25 & 0.06 & 0.47 & - & 0.52 & - & 0.45 & - & 0.43 & - \\
\hline $\mathrm{MgO}$ & 7.79 & 1.35 & 6.15 & 1.41 & 5.25 & 0.45 & 4.15 & 0.59 & 3.15 & 0.77 & 2.32 & 0.67 \\
\hline $\mathrm{CaO}$ & 0.16 & 0.13 & 0.17 & 0.15 & - & - & - & - & - & 0.05 & - & - \\
\hline $\mathrm{Na}_{2} \mathrm{O}$ & 0.67 & 0.72 & 0.57 & 0.99 & 0.25 & 0.54 & 0.34 & 0.46 & 0.28 & 0.54 & 0.38 & 0.47 \\
\hline $\mathrm{K}_{2} \mathrm{O}$ & 9.52 & 10.38 & 9.40 & 10.12 & 8.95 & 10.44 & 9.15 & 10.48 & 9.55 & 10.39 & 9.29 & 10.58 \\
\hline $\mathrm{Cl}$ & 0.07 & - & 0.01 & - & 0.10 & - & 0.14 & - & 0.08 & - & 0.03 & - \\
\hline \multirow[t]{2}{*}{$\mathrm{F}$} & 0.54 & 0.17 & 0.30 & 0.26 & 0.38 & 0.19 & 0.38 & 0.33 & 0.82 & 1.11 & 1.58 & 0.51 \\
\hline & 96.73 & 96.21 & 96.34 & 96.29 & 96.25 & 95.23 & 96.14 & 95.06 & 96.94 & 96.15 & 97.54 & 95.42 \\
\hline $\mathrm{O} \equiv \mathrm{Cl}$ & 0.02 & - & - & - & 0.02 & - & 0.03 & - & 0.02 & - & 0.01 & - \\
\hline $\mathrm{O} \equiv \mathrm{F}$ & 0.23 & 0.07 & 0.13 & 0.11 & 0.16 & 0.08 & 0.16 & 0.14 & 0.34 & 0.47 & 0.66 & 0.21 \\
\hline Total & 96.48 & 96.14 & 96.21 & 96.18 & 96.07 & 95.15 & 95.95 & 94.92 & 96.58 & 95.68 & 96.87 & 95.21 \\
\hline $\mathrm{Cr}$ & 135 & 31 & 103 & 24 & 35 & 32 & 32 & 27 & 52 & 33 & 22 & 24 \\
\hline V & 237 & 103 & 122 & 80 & 41 & 32 & 45 & 18 & 89 & 44 & 24 & 21 \\
\hline $\mathrm{Nb}$ & 153 & 51 & 233 & 96 & 233 & 120 & 331 & 110 & 244 & 95 & 332 & 112 \\
\hline $\mathrm{Zn}$ & 774 & 58 & 746 & 76 & 1451 & 228 & 1709 & 265 & 1548 & 172 & 1779 & 296 \\
\hline $\mathrm{Sn}$ & 13 & 7 & 12 & 13 & 24 & 62 & 24 & 147 & 39 & 125 & 43 & 89 \\
\hline $\mathrm{Li}$ & 839 & 186 & 1204 & 262 & 1231 & 399 & 1383 & 1008 & 1421 & 919 & 1645 & 912 \\
\hline $\mathrm{Ni}$ & 53 & 26 & 31 & 22 & 37 & 10 & 39 & 12 & 59 & 17 & 35 & 16 \\
\hline $\mathrm{Sc}$ & 15 & 19 & 6 & 16 & $*$ & 8 & $*$ & 14 & $*$ & 11 & 8 & 25 \\
\hline $\mathrm{Y}$ & 62 & 45 & 74 & 57 & 36 & 19 & 36 & 28 & 26 & 21 & 42 & 25 \\
\hline $\mathrm{Sr}$ & 23 & 35 & 20 & 24 & 19 & 20 & 16 & 18 & 15 & 15 & 18 & 16 \\
\hline $\mathrm{Ba}$ & 383 & 745 & 126 & 265 & 37 & 127 & 12 & 90 & 31 & 77 & 10 & 55 \\
\hline $\mathrm{Rb}$ & 1381 & 805 & 1806 & 1307 & 1579 & 854 & 1704 & 1272 & 2257 & 1415 & 2476 & 1473 \\
\hline $\mathrm{Cs}$ & 77 & 18 & 88 & 42 & 349 & 24 & 410 & 88 & 748 & 97 & 322 & 49 \\
\hline
\end{tabular}

Column headings as in Table 2. - not detected; * below the limit of sensitivity. 
Table 8. Chemical analyses in wt.\% and trace elements in ppm of coexisting biotite and muscovite of granites from Serra da Estrela and Carregal do Sal - Nelas - Lagares da Beira, central Portugal.

\begin{tabular}{|c|c|c|c|c|c|c|c|c|c|c|}
\hline & \multicolumn{6}{|c|}{ Serra da Estrela } & \multicolumn{4}{|c|}{ Carregal do Sal - Nelas - Lagares da Beira } \\
\hline & $\begin{array}{l}\text { Biotite } \\
6-c\end{array}$ & $\begin{array}{l}\text { Muscovite } \\
6-c\end{array}$ & $\begin{array}{l}\text { Biotite } \\
6-d\end{array}$ & $\begin{array}{l}\text { Muscovite } \\
6-d\end{array}$ & $\begin{array}{l}\text { Biotite } \\
6 \text {-e }\end{array}$ & $\begin{array}{l}\text { Muscovite } \\
6 \text {-e }\end{array}$ & $\begin{array}{l}\text { Biotite } \\
7-c\end{array}$ & $\begin{array}{l}\text { Muscovite } \\
7-c\end{array}$ & $\begin{array}{l}\text { Biotite } \\
7-d\end{array}$ & $\begin{array}{l}\text { Muscovite } \\
7-d\end{array}$ \\
\hline $\mathrm{SiO}_{2}$ & 36.24 & 47.29 & 34.82 & 47.60 & 34.32 & 47.09 & 35.23 & 47.02 & 35.12 & 46.68 \\
\hline $\mathrm{TiO}_{2}$ & 2.60 & 0.58 & 2.32 & 0.43 & 2.65 & 0.29 & 2.68 & 0.91 & 2.81 & 0.73 \\
\hline $\mathrm{Al}_{2} \mathrm{O}_{3}$ & 19.10 & 34.19 & 19.03 & 34.78 & 18.93 & 34.43 & 19.35 & 34.86 & 19.52 & 34.17 \\
\hline $\mathrm{Fe}_{2} \mathrm{O}_{3}$ & 0.91 & 0.12 & 1.24 & 0.26 & 0.82 & 1.01 & 3.39 & 0.71 & 2.98 & 0.46 \\
\hline $\mathrm{FeO}$ & 24.17 & 1.64 & 25.68 & 1.30 & 27.52 & 1.33 & 19.60 & 1.08 & 20.71 & 1.45 \\
\hline $\mathrm{MnO}$ & 0.14 & - & 0.65 & - & 0.53 & - & 0.27 & 0.03 & 0.42 & 0.05 \\
\hline $\mathrm{MgO}$ & 4.11 & 0.49 & 2.93 & 0.31 & 1.69 & - & 5.31 & 0.52 & 4.78 & 1.00 \\
\hline $\mathrm{CaO}$ & - & - & - & - & - & - & 0.02 & 0.01 & 0.03 & 0.03 \\
\hline $\mathrm{Na}_{2} \mathrm{O}$ & 0.06 & 0.64 & 0.02 & 0.64 & 0.08 & 0.43 & 0.18 & 0.64 & 0.23 & 0.58 \\
\hline $\mathrm{K}_{2} \mathrm{O}$ & 9.59 & 10.52 & 9.22 & 10.50 & 9.17 & 10.82 & 9.10 & 10.19 & 9.19 & 10.17 \\
\hline $\mathrm{Cl}$ & 0.05 & - & 0.04 & - & 0.14 & - & 0.05 & 0.03 & 0.05 & 0.02 \\
\hline \multirow{2}{*}{$\mathrm{F}$} & 0.55 & 0.37 & $\begin{array}{l}0.69 \\
0.69\end{array}$ & 0.36 & 0.47 & 0.31 & 0.60 & 0.48 & 0.49 & 0.40 \\
\hline & 97.52 & 95.84 & 96.64 & 96.18 & 96.32 & 95.71 & 95.78 & 96.48 & 96.33 & 95.74 \\
\hline $\mathrm{O} \equiv \mathrm{Cl}$ & 0.01 & - & 0.01 & - & 0.03 & - & 0.01 & 0.01 & 0.01 & - \\
\hline $\mathrm{O} \equiv \mathrm{F}$ & 0.23 & 0.16 & 0.29 & 0.15 & 0.20 & 0.13 & 0.25 & 0.20 & 0.21 & 0.17 \\
\hline Total & 97.28 & 95.68 & 96.34 & 96.03 & 96.09 & 95.58 & 95.52 & 96.27 & 96.11 & 95.57 \\
\hline $\mathrm{Cr}$ & 65 & 34 & 29 & 23 & 20 & 24 & 70 & 22 & 113 & 20 \\
\hline $\mathrm{V}$ & n.d. & n.d. & n.d. & n.d. & n.d. & $*$ & 212 & 133 & 172 & 98 \\
\hline $\mathrm{Nb}$ & 178 & 39 & 205 & 43 & 233 & 38 & 121 & 82 & 289 & 95 \\
\hline $\mathrm{Zn}$ & 1540 & 217 & 1843 & 127 & 2250 & 250 & 581 & 94 & 875 & 109 \\
\hline Sn & 32 & 88 & 28 & 77 & 29 & 69 & 191 & 194 & 177 & 202 \\
\hline $\mathrm{Li}$ & 1718 & 485 & 1086 & 340 & 1864 & 306 & 1478 & 321 & 1948 & 507 \\
\hline $\mathrm{Ni}$ & 30 & 18 & 8 & 16 & $*$ & 19 & 31 & 24 & 24 & 23 \\
\hline $\mathrm{Sc}$ & 16 & 24 & 5 & 22 & $*$ & 9 & 51 & 81 & 22 & 43 \\
\hline Y & 54 & 67 & 77 & 62 & 95 & 61 & 99 & 25 & 138 & 47 \\
\hline $\mathrm{Sr}$ & 9 & 20 & 16 & 22 & $*$ & $*$ & n.d. & n.d. & n.d. & n.d. \\
\hline $\mathrm{Ba}$ & 206 & 156 & 36 & 132 & * & 5 & 123 & 682 & 87 & 453 \\
\hline $\mathrm{Rb}$ & 1658 & 1104 & 1600 & 997 & 1863 & 1081 & 1703 & 1006 & 1786 & 1218 \\
\hline $\mathrm{Cs}$ & 134 & 57 & 142 & 47 & 140 & 39 & 126 & 43 & 124 & 41 \\
\hline
\end{tabular}

Column headings as in Table 3. - not detected; n.d. - not determined;* below the limit of sensitivity. 
Table 9. Chemical analyses in wt.\% and trace elements in ppm of coexisting biotite and muscovite of granitic rocks from Penamacor - Monsanto, central Portugal.

\begin{tabular}{|c|c|c|c|c|}
\hline & $\begin{array}{l}\text { Biotite } \\
8-c\end{array}$ & $\begin{array}{l}\text { Muscovite } \\
8-c\end{array}$ & $\begin{array}{l}\text { Biotite } \\
8-d\end{array}$ & $\begin{array}{l}\text { Muscovite } \\
\text { 8-d }\end{array}$ \\
\hline $\mathrm{SiO}_{2}$ & 35.92 & 46.13 & 35.58 & 45.90 \\
\hline $\mathrm{TiO}_{2}$ & 3.21 & 0.31 & 2.39 & 0.33 \\
\hline $\mathrm{Al}_{2} \mathrm{O}_{3}$ & 19.91 & 35.71 & 20.42 & 36.07 \\
\hline $\mathrm{Fe}_{2} \mathrm{O}_{3}$ & 2.65 & 0.09 & 2.87 & 0.13 \\
\hline $\mathrm{FeO}$ & 20.65 & 0.99 & 21.99 & 1.27 \\
\hline $\mathrm{MnO}$ & - & - & - & - \\
\hline $\mathrm{MgO}$ & 5.86 & 0.52 & 4.48 & 0.51 \\
\hline $\mathrm{CaO}$ & - & - & 0.09 & 0.07 \\
\hline $\mathrm{Na}_{2} \mathrm{O}$ & - & 0.53 & 0.58 & 0.82 \\
\hline $\mathrm{K}_{2} \mathrm{O}$ & 9.50 & 10.16 & 8.95 & 10.25 \\
\hline $\mathrm{Cl}$ & 0.03 & - & 0.02 & - \\
\hline \multirow[t]{2}{*}{$\mathrm{F}$} & 0.36 & 0.12 & 0.40 & 0.24 \\
\hline & 98.09 & 94.56 & 97.77 & 95.59 \\
\hline $\mathrm{O} \equiv \mathrm{Cl}$ & 0.01 & - & - & - \\
\hline $\mathrm{O} \equiv \mathrm{F}$ & 0.15 & 0.05 & 0.17 & 0.10 \\
\hline Total & 97.93 & 94.51 & 97.60 & 95.49 \\
\hline $\mathrm{Cr}$ & 154 & 50 & 109 & 29 \\
\hline V & 76 & 37 & 38 & $*$ \\
\hline $\mathrm{Nb}$ & 136 & 22 & 230 & 54 \\
\hline $\mathrm{Zn}$ & 943 & 102 & 1839 & 178 \\
\hline Sn & $*$ & 51 & 67 & 145 \\
\hline $\mathrm{Li}$ & 1122 & 132 & 1818 & 689 \\
\hline $\mathrm{Ni}$ & 62 & 9 & 27 & 19 \\
\hline $\mathrm{Sc}$ & 35 & 26 & 25 & 19 \\
\hline $\mathrm{Y}$ & 66 & 32 & 76 & 62 \\
\hline $\mathrm{Sr}$ & n.d. & n.d. & n.d. & n.d. \\
\hline $\mathrm{Ba}$ & 268 & 272 & 23 & 51 \\
\hline $\mathrm{Rb}$ & 1583 & 790 & 1977 & 1505 \\
\hline $\mathrm{Cs}$ & n.d. & n.d. & n.d. & n.d. \\
\hline
\end{tabular}

Column headings as in Table 3. - not detected; * below the limit of sensitivity; n.d. - not determined.

$\mathrm{Ba}^{3+}(13.4 \mathrm{~nm}), \mathrm{Rb}^{+}(14.8 \mathrm{~nm})$ and $\mathrm{Cs}^{+}(16.7 \mathrm{~nm})$ mainly replace $\mathrm{K}^{+}(13.3 \mathrm{~nm})$ in both biotite and muscovite. So they will be accommodated in the interlayer site, which will be smaller in muscovite than in biotite (Shearer et al. 1986). Consequently these elements, particular the larger ones, would be expected to favour biotite as found in this study and as has been documented by other studies of coexisting micas from granitic rocks (Albuquerque 1975; Mittlefehlt and Miller 1983; Shearer et al. 1986; Jolliff et al. 1992; Hall et al. 1993; Bea et al. 1994; Neves 1997) as well as by experimental studies (Icenhower and London 1995). The partition ratio for Cs of series 6 (Table 10) is similar to that found experimentally (Icenhower and London 1995), but lower than that found in Viseu area (Neves 1997). However Ba favours muscovite rather than biotite (Tables 4-9) as found by Albuquerque (1975), Lee et al. (1981), Kretz et al. (1989), Jolliff et al. (1992) and Bea et al. (1994), but experimental data shows the preference of Ba for biotite (Icenhower and London 1995).

\section{Relationships among biotites, muscovites and host rocks}

In granitic rocks, micas retain most of $\mathrm{Cr}, \mathrm{V}, \mathrm{Zn}, \mathrm{Y}, \mathrm{Ni}$ and $\mathrm{Li}$ contents. Commonly biotite has higher contents of these trace elements than coexisting muscovite (Tables 4 to 
Table 10. Calculated average partition coefficient of trace elements between biotite and muscovite from Portuguese granitic series of differentiation

\begin{tabular}{|c|c|c|c|c|c|c|c|}
\hline & Rebordelo & Ervedosa & Jales & $\begin{array}{l}\text { Alijó- } \\
\text { Sanfins }\end{array}$ & Torrão & $\begin{array}{l}\text { Serra } \\
\text { da Estrela }\end{array}$ & $\begin{array}{l}\text { Carregal } \\
\text { do Sal }\end{array}$ \\
\hline & $1 \mathrm{a}$ & $1 b$ & 2 & 3 & 4 & 6 & 7 \\
\hline $\mathrm{Cr}$ & $\begin{array}{l}50+1.1 / \\
\mathrm{Cr}_{\text {mus }}\end{array}$ & & 2.0 & & 4.4 & $\begin{array}{l}-37+2.9 / \\
\mathrm{Cr}_{\text {mus }}\end{array}$ & \\
\hline V & $\begin{array}{l}130+0.92 / \\
\mathrm{V}_{\text {mus }}\end{array}$ & & & & $\begin{array}{l}-251+4.7 / \\
\mathrm{V}_{\text {mus }}\end{array}$ & & \\
\hline $\mathrm{Nb}$ & $\begin{array}{l}-30+2.4 / \\
\mathrm{Nb}_{\text {mus }}\end{array}$ & & $\begin{array}{l}-204+6.8 / \\
\mathrm{Nb}_{\text {mus }}\end{array}$ & & & & \\
\hline $\mathrm{Zn}$ & & & $66+11 / \mathrm{Zn}_{\text {mus }}$ & & & & \\
\hline $\mathrm{Sn}$ & & & & & & $\begin{array}{l}-38+0.83 / \\
\mathrm{Sn}_{\text {mus }}\end{array}$ & \\
\hline $\mathrm{Li}$ & $\begin{array}{l}291+3.5 / \\
\mathrm{Li}_{\text {mus }}\end{array}$ & $\begin{array}{l}582+2.8 / \\
\mathrm{Li}_{\text {mus }}\end{array}$ & $\begin{array}{l}467+4.1 / \\
\mathrm{Li}_{\text {mus }}\end{array}$ & & $\begin{array}{l}197+3.7 / \\
\mathrm{Li}_{\text {mus }}\end{array}$ & & $\begin{array}{l}817+2.2 / \\
\mathrm{Li}_{\text {mus }}\end{array}$ \\
\hline $\mathrm{Y}$ & & & & & $17+0.99 / \mathrm{Y}_{\mathrm{mus}}$ & & \\
\hline $\mathrm{Ba}$ & & & & & $\begin{array}{l}-13+0.53 / \\
\mathrm{Ba}_{\text {mus }}\end{array}$ & & \\
\hline $\mathrm{Rb}$ & $\begin{array}{l}506+1.2 / \\
\mathrm{Rb}_{\text {mus }}\end{array}$ & $\begin{array}{l}-411+2.4 / \\
\mathrm{Rb}_{\text {mus }}\end{array}$ & $\begin{array}{l}222+1.9 / \\
\mathrm{Rb}_{\text {mus }}\end{array}$ & & $\begin{array}{l}708+0.84 / \\
\mathrm{Rb}_{\text {mus }}\end{array}$ & & $\begin{array}{l}621+0.96 / \\
\mathrm{Rb}_{\text {mus }}\end{array}$ \\
\hline Cs & & & $\begin{array}{l}94+8.9 / \\
\mathrm{Cs}_{\text {musc }}\end{array}$ & $\begin{array}{l}-113+6.8 / \\
\mathrm{Cs}_{\text {musc }}\end{array}$ & & 2,8 & \\
\hline $\mathrm{n}$ & 8 & 16 & 13 & 4 & 6 & 10 & 14 \\
\hline
\end{tabular}

9). The amount of biotite decreases, while that of muscovite increases in each differentiation series. Therefore generally $\mathrm{Cr}, \mathrm{V}, \mathrm{Zn}$ and $\mathrm{Y}$ decrease in granitic rocks during differentiation as well as Ni when detected (Tables 1, 2 and 3). However Li generally increases in granitic rocks during differentiation, which is attributed to the fact that the increase in Li content of muscovite is higher than that of coexisting biotite during differentiation in those series and the amount of muscovite increases.

In the tin-bearing granites from Ervedosa and Alijó-Sanfins, the majority of the granite $\mathrm{Sn}$ is held in muscovite and it commonly increases with differentiation, mainly because the amount of muscovite increases, while that of biotite decreases.

$\mathrm{Sr}$ of granitic rocks will be mainly retained in plagioclase. However K-feldspar is richer in Sr than coexisting albite (Neiva 1977). Micas play a very small role in the Sr content of host granitic rocks.

$\mathrm{Rb}$ content of granitic rocks is mainly retained in micas and K-feldspar. Commonly biotite has higher $\mathrm{Rb}$ content than coexisting muscovite (Tables 4 to 9), but also similar to higher $\mathrm{Rb}$ content than coexisting K-feldspar as found in granites from Alijó-Sanfins (Neiva 1973). The increase in the amount of muscovite through the differentiation series favours the increase in $\mathrm{Rb}$ content of granitic rocks during differentiation (Tables 1, 2 and 3).

As Ba replaces mainly K, K-feldspar has a higher Ba content than coexisting micas (Neiva 1973). However, the decrease in the amount of biotite through the differentiation series contributes to the decrease in Ba content of the host granitic rocks. 


\section{Conclusions}

- The behaviours of $\mathrm{Cr}, \mathrm{V}, \mathrm{Sc}, \mathrm{Ba}, \mathrm{Nb}, \mathrm{Zn}, \mathrm{Sn}, \mathrm{Li}, \mathrm{Rb}$ and $\mathrm{Cs}$ in primary biotite (mainly $\mathrm{Fe}^{2+}$-biotite and siderophyllite) and muscovite from nine peraluminous granitic differentiation series are controlled by fractionation of granitic melts.

- Disequilibrium commonly occurs for trace elements between coexisting micas. Regression lines of correlations for trace elements between coexisting micas generally do not pass through the origin due to solid-liquid reequilibrium during late-magmatic evolution.

- Correlations for $\mathrm{Cr}, \mathrm{V}, \mathrm{Nb}, \mathrm{Li}, \mathrm{Rb}$ and $\mathrm{Cs}$ between coexisting biotite and muscovite show different slopes in several series due to different degrees of fractional crystallization and solid-liquid reequilibration during late-magmatic evolution.

- In general, $\mathrm{Cr}, \mathrm{V}, \mathrm{Nb}, \mathrm{Zn}, \mathrm{Li}$ and $\mathrm{Ni}$ prefer biotite rather than muscovite, because they are accommodated in octahedral sites replacing major elements, which have higher contents in biotite than muscovite.

- In unaltered tin-bearing granites, most of the granite Sn is held by muscovite and it increases during differentiation mainly due to increase in the amount of muscovite.

- Biotite has higher $\mathrm{Rb}$ and $\mathrm{Cs}$ contents than coexisting muscovite, because these trace elements replace $\mathrm{K}$ and are accommodated in the interlayer site, which is smaller in muscovite than biotite.

- The partition ratio for Cs in the Serra da Estrela series is 2.8 and similar to that found experimentally.

- Y probably replaces $\mathrm{Ca}$ and prefers biotite, while $\mathrm{Sr}$ and $\mathrm{Ba}$ generally have higher contents in muscovite than coexisting biotite. The behaviour of $\mathrm{Sr}$ is supported by experimental data and other studies, while that of $\mathrm{Ba}$ is distinct from that of experimental data, but it is in accordance with findings of other authors.

- In granitic rocks, $\mathrm{Cr}, \mathrm{V}, \mathrm{Zn}, \mathrm{Sn}, \mathrm{Y}, \mathrm{Ni}$ and Li contents are mainly retained in micas, it is conect in biotite, while $\mathrm{Sr}$ is concentrated in plagioclase and $\mathrm{Rb}$ and $\mathrm{Ba}$ occur mainly in $\mathrm{K}$-feldspar, but also in micas.

\section{Acknowledgements}

This research work belongs to the programme of Geosciences Centre, University of Coimbra, Portugal. This paper benefitted from the helpful comments of an anonymous referee.

\section{References}

Albuquerque CAR (1975) Partition of trace elements in co-existing biotite, muscovite and potassium feldspar of granitic rocks, northern Portugal. Chem Geol 16, 89-108

Bea F, Câmara F, Fernandez Soler JM, Gomez Pugnaire MT, Pereira MD, Stroh A (1993) Trace element determination in minerals. Analysis of concentrates versus laser ablation techniques. Case study: biotites from granitic rocks. Europ Winter Conf Plasma Spectr, P 240 (abstr)

Bea F, Pereira MD, Corretgé LG, Fershtater GB (1994) Differentiation of strongly peraluminous, phosphorus granites: The Pedrobernardo pluton, central Spain. Geochim Cosmochim Acta 58, 2609-2628

Beattie P, Drake M, Jones J, Leeman W, Longhi J, McKay G, Nielsen R, Palme H, Shaw D, Takahashi E, Watson B (1993) Terminology for trace-element partitioning. Geochim Cosmochim Acta 57, 1605-1606

Brigatti MF, Frigieri P, Ghezzo C, Poppi L (2000) Crystal chemistry of Al-rich biotites coexisting with muscovites in peraluminous granites. Amer Mineral 85, 436-448

Brown G, Hughes DJ, Esson J (1973) New X.R.F. data retrieval techniques and their applications to U.S.G.S. standard rocks. Chem Geol 11, 223-229 
Carron JP, Lagache M (1972) Étude du partage des éléments alcalins Na, K, Li, Rb et Cs entre les minéraux de quelques roches granitiques de France. $24^{\text {th }}$ Int Geol Cong Sec 10, 60-66

Foster MD (1960) Interpretation of triocthaedral micas. U.S. Geol Surv Prof Pap 354B, 1-49

Gomes MEP (1996) Mineralogia, petrologia e geoquímica das rochas granitóides da área de Rebordelo - Bouça - Torre de C. Chama - Agrochão e as mineralizações associadas. Unpublished Ph.D. thesis, Univ. of Trásos-Montes e Alto Douro, 323 pp

Gomes MEP and Neiva AMR (2002). Petrogenesis of tin-bearing granites from Ervedosa, northern Portugal: The imfortance of magmatic processes. Chem Erde 62, 47-72

Hall A, Jarvis KE, Walsh JN (1993) The variation of cesium and 37 other elements in the Sardinian granite batholith, and the significance of cesium for granite petrogenesis. Contrib Mineral Petrol 114, 160-170

Hesp WR (1971) Correlation between the tin content of granitic rocks and their chemical and mineralogical composition. Geochemical Exploration. Canadian Inst Mining Metallurgy Spec Publ 11, 341-353

Icenhower J, London D (1995) An experimental study of element partitioning among biotite, muscovite and coexisting peraluminous silicic melt at $200 \mathrm{MPa}\left(\mathrm{H}_{2} \mathrm{O}\right)$. Amer Mineral 80, 1229-1251

Jolliff BL, Papike JJ, Shearer CK (1992) Petrogenetic relationships between pegmatite and granite based on geochemistry of muscovite in pegmatite wall zones, Black Hills, South Dakota, U.S.A. Geochim Cosmochim Acta 56, 1915-1939

Kretz R, Loop J, Hartree R (1989) Petrology and Li-Be-B geochemistry of muscovite-biotite granite and associated pegmatite near Yellowknife, Canada. Contrib. Mineral Petrol 102, 174-190

Lee de, Kistler RW, Friedman I, van Loenen RE (1981) Two-mica granites of Northeastern Nevada. J Geophys Res 86, 10607-10616

Miller CF, Stoddard EF, Bradfish LJ, Dollase WA (1981) Composition of plutonic muscovite: genetic implications. Can Mineral 19, 25-34

Mittlefehldt DW, Miller CF (1983) Geochemistry of the Sweetwater Wash pluton, California. Geochim Cosmochim Acta 47, 109-124

Monier G, Mergoli J, Labernardière H (1984) Générations successives de muscovites et feldspars potassiques dans les leucogranites du massif de Millevaches (Massif Central Français). Bull Minéral 107, 55-68

Neiva AMR (1973) Geochemistry of the granites and their minerals from the central area of northern Portugal. Mem Not Mus Lab Min Geol, Univ Coimbra 76, 1-43

Neiva AMR (1976) Geochemistry of biotites from central northern Portugal and the role of their tin content. Min Mag 40, 453-466

Neiva AMR (1977) Distribution of some elements between coexisting minerals from granites, aplites and pegmatites from central northern Portugal. Chem Geol 20, 223-233

Neiva AMR (1984) Geochemistry of tin-bearing granitic rocks. Chem Geol 43, 241-256

Neiva AMR (1993) Geochemistry of granites and their minerals from Gerez mountain, northern Portugal. Chem Erde 53, 227-258

Neiva AMR (1998) Geochemistry of highly peraluminous granites and their minerals between Douro and Tamega valleys, northern Portugal. Chem Erde 58, 161-184

Neiva AMR, Campos TFC (1992) Genesis of the zoned granitic pluton of Penamacor-Monsanto, central Portugal. Mem Not Mus Lab Mineral Geol, Univ Coimbra 114, 51-68

Neiva AMR, Gomes MEP (1991) Geochemistry of the granitoid rocks and their minerals from Lixa do Alvão Alfarela de Jales - Tourencinho (Vila Pouca de Aguiar, northern Portugal). Chem Geol 89, 305-327

Neiva AMR, Neiva JMC, Parry SJ (1987) Geochemistry of the granitic rocks and their minerals from Serra da Estrela, central Portugal. Geochim Cosmochim Acta 51, 439-454

Neves JPF (1997) Trace element content and partition between biotite and muscovite of granitic rocks: a study in the Viseu region (Central Portugal). Eur J Mineral 9, 849-857

Norrish K, Hutton JI (1969) An accurate X-ray spectrographic method for the analysis of a wide range of geological samples. Geochim Cosmochim Acta 33, 431-453

Shearer CK, Papike JJ, Simon SB (1986) Pegmatite wall-rock interactions, Black Hills, South Dakota: Interaction between pegmatite-derived fluids and quartz-mica schist wallrock. Amer Mineral 71, 518-539

Silva MMVG (1995) Mineralogia, petrologia e geoquímica de encraves de rochas graníticas de algumas regiões portuguesas. Unpublished Ph. D. thesis, Univ. of Coimbra, $288 \mathrm{pp}$

Silva MMVG, Neiva AMR (1990) Geochemistry of the granites and their minerals from Paredes da Beira Penedono, northern Portugal. Chem Geol 85, 147-170

Silva MMVG, Neiva AMR (2000) Geochemistry of Hercynian peraluminous granites and their minerals from Carregal do Sal - Nelas - Lagares da Beira area, central Portugal. Chem Erde 59, 329-349

Tischendorf G, Foster H-J, Gottesmann B (2001) Minor- and trace-element composition of trioctahedral micas: a review. Mineral Mag 65, 249-276 